Krzysztof Śleziński ${ }^{1}$

Uniwersytet Śląski w Katowicach

\title{
DYDAKTYKA OGÓLNA I DYDAKTYKI SZCZEGÓŁOWE W POLSKIEJ MYŚLI PEDAGOGICZNEJ - ANALIZA WYBRANYCH PROBLEMÓW
}

General and Specific Didactics in Polish Pedagogical Thought - An Analysis of Selected Problems

S u m m a ry: In the article the author presents a path whereby specific didactics, also called subject didactics, are acquired in order to gain scientific autonomy. The author also draws attention to the strict dependence of specific didactics on general didactics and the specificity of the subjects they teaching. The importance of the development of didactics in the creation of appropriate structures for the academic community is also emphasized.

Keyw ord s: general didactics, specific didactics, methodics, reform of education, educational program

\section{Wprowadzenie}

Zastanawiając się nad rozwojem dydaktyki ogólnej oraz dydaktyk szczegółowych, słuszniej określanych dydaktykami przedmiotowymi, nie sposób pominąć ogólnie zachodzących zmian w rzeczywistości oświatowej. W latach 1939-2016 dostrzegamy przeprowadzane ze zmiennym natężeniem reformy szkolne. Propozycje reform nie są z góry czymś złym, mającym burzyć dotychczasowe dobre praktyki pedagogiczne i dydaktyczne, lecz wynikają z konieczności udoskonalania działalności edukacyjnej oraz dostosowywania się do zmieniających się

${ }^{1}$ Dr hab. Krzysztof Śleziński, prof. UŚ - jest dyrektorem Instytutu Nauk o Edukacji na Wydziale Etnologii i Nauk o Edukacji w Cieszynie Uniwersytetu Śląskiego w Katowicach. Adres: INoE UŚ, ul. Bielska 62, 43-400 Cieszyn; e-mail: krzysztof.slezinski@us.edu.pl. 
wyzwań, przed którymi stają konkretny człowiek i całe społeczeństwa. Pozostawienie systemu edukacyjnego na określonym poziomie przy zmieniających się czynnikach demograficznych, ekonomicznych, kulturowych, społecznych, politycznych, naukowo-technicznych, a także wychowawczych skutkuje nie tylko stagnacją, ale przede wszystkim regresem stanu oświaty i poziomu kształcenia $\mathrm{w}$ danym społeczeństwie. Zmianom w szkolnictwie powinna towarzyszyć solidna diagnoza zastanego stanu, pozwalająca określić perspektywy wprowadzenia koniecznych reform. Przy czym zmienność i żywiołowość oddziaływania wielu wymienionych czynników może być częstym powodem powodzenia lub niepowodzenia określonej reformy. I chociaż dla pedagogów reformy powinny być dobrze opracowane w teorii i empirycznie, pilotażowo sfalsyfikowane, to jednak okazuje się, że w reformach szkolnictwa mamy do czynienia z prymatem polityki i ideologii².

Reformy szkolne służyć mają przede wszystkim polityce. W skrajnych wypadkach, czego doświadczyliśmy na naszym rodzimym gruncie edukacyjnym, politycy dążyli i dążą do całkowitego podporządkowania szkoły i pozaszkolnych instytucji oświatowych swoim potrzebom. Za każdym razem te niezbyt dobrze przemyślane reformy podejmowane w Polsce Ludowej nie mogły się zakończyć sukcesem. Przedstawimy kilka faktów dotyczących systemu szkolnego, które mają duże przełożenie na jedynie wybiórcze omówienie problematyki określonej w temacie niniejszego artykułu.

\section{Reforma szkolnictwa i jej przełożenie na przedmiotowe programy kształcenia}

Okres powojenny, w którym próbowano budować jedynie pedagogikę socjalistyczną, nie był wcale jednostronny i ograniczony. Teoretyczna wiedza pedagogiczna tego okresu dostarcza danych świadczących o jej stosunkowo dużym zróżnicowaniu. Występujące nurty i orientacje pedagogiczne $\mathrm{z}$ jednej strony przejmowały doświadczenia polskiej pedagogiki okresu międzywojennego, a z drugiej otwierały się na różne odmiany pedagogiki zachodniej - szczególnie w latach 80 . i 90., kiedy mieliśmy do czynienia z przemianami polityczno-społecznymi. Ponadto w okresie powojennym miał miejsce wyraźny postęp w opracowywaniu metodologii badań pedagogicznych oraz rozwoju teorii kształcenia ${ }^{3}$. $\mathrm{W}$ niniejszym tekście interesuje mnie to ostatnie zagadnienie.

${ }^{2}$ Mirosław Szymański, „Podstawy teoretyczne reform szkolnych”, w: Możliwości rozwijania i wykorzystywania teoretycznej wiedzy pedagogicznej, red. Stanisław Palka, Zeszyty Naukowe Uniwersytetu Jagiellońskiego MCLXI, Prace Pedagogiczne 22 (1995): 57-64.

${ }^{3}$ Stanisław Palka, „Zróżnicowanie teoretycznej wiedzy pedagogicznej a praktyka pedagogiczna”, w: Możliwości rozwijania i wykorzystywania teoretycznej wiedzy pedagogicznej, 173-176. 
W latach 1945-1949 kontynuowano model zreformowanej szkoły z 1932 roku, w której zgodnie z zaleceniami dydaktycznymi dążono do skorelowania treści wśród przedmiotów sobie pokrewnych lub zajmujących się w różnych perspektywach tym samym przedmiotem badań. Wyznaczano cele odnoszące się do doskonalenia umiejętności i postaw, a nabywanie wiadomości uważano za sprawę drugorzędną. Programy szkolne cechowało ubóstwo materiału faktycznego. W okresie powojennym krytyka formalizmu dydaktycznego z biegiem czasu doprowadziła do innej skrajności, jaką był materializm dydaktyczny. Zanim jednak zaistniał, wcześniej, pod koniec lat 40. wprowadzono 11-letnią szkołę ogólnokształcącą na wzór istniejącej w Związku Radzieckim, co doprowadziło do zburzenia polskiego systemu szkolnego. Głównym celem kształcenia i wychowania było wprowadzanie podstaw materialistycznego naukowego światopoglądu i moralności socjalistycznej ${ }^{4}$. Kolejna zmiana programowa w roku 1961 skorelowana z wprowadzeniem ośmiu klas szkoły podstawowej i czterech licealnych oraz klas techników umożliwiała integrowanie treści nauczania w obrębie przedmiotów sobie pokrewnych. Kontynuowanie tych dążeń doprowadziło do wprowadzenia w 1973 roku sprofilowanych klas licealnych: matematyczno-fizycznych, chemiczno-biologicznych, humanistycznych i klasycznych.

Badania nad funkcjonalnością kolejnych wersji projektów programów kształcenia z poszczególnych przedmiotów oraz powołanie Komitetu Ekspertów w latach 1971-1973 pod kierunkiem prof. Jana Szczepańskiego miały usprawiedliwiać wprowadzenie pod koniec lat 70. „dziesięciolatki”. Projekt ten, niewiele mający wspólnego z propozycjami ekspertów, nie został jednak wdrożony. Rezygnacja $\mathrm{z}$ tak daleko idącej reformy systemu szkolnego doprowadziła do wielu zmian w koncepcjach programowych nauczania poszczególnych przedmiotów. W podręcznikach szkolnych opartych na założeniach materializmu dydaktycznego niewspółmiernie do haseł programowych wzrósł zakres treści kształcenia. Dostrzeżone narastające obciążenie uczniów wiadomościami encyklopedycznymi doprowadziło w latach 1987-1990 do kilku nieskutecznych prób redukowania treści kształcenia w poszczególnych przedmiotach. W 1989 roku raport Edukacja narodowym priorytetem, celnie przedstawiający liczne wady istniejącego systemu oświatowego, przygotowany przez Komitet Ekspertów kierowany przez prof. Czesława Kupisiewicza, nie został spożytkowany przez nowe władze oświatowe w demokratycznej już Polsce 5 . Manifestowane odcięcie się od wszystkiego, co dokonywało się we wcześniejszym okresie, i propagowanie nowej polityki wprowadzającej liberalno-monetarystyczną reformę gospodarczą Leszka Balcerowicza zepchnęly oświatę do drugoplanowej sfery działań państwowych.

Od 2000 roku wdrażano kolejną reformę szkolną, wprowadzającą trzyletnie gimnazja i licea oraz sześcioletnią szkołę podstawową. Aż po dzień dzisiejszy

\footnotetext{
${ }^{4}$ Wiesław Stawiński, Główne nurty rozwoju dydaktyki biologii (Warszawa: WSiP 1992), 29.

${ }^{5}$ Szymański, „Podstawy teoretyczne reform szkolnych”, 59-60.
} 
okres ten cechuje materializm dydaktyczny. Głównym zadaniem pedagogiki i edukacji stało się ukształtowanie nowej świadomości krytycznej, a silny wpływ neoliberalnych reform edukacji przyczynił się do traktowania efektów kształcenia jako najważniejszych wyznaczników edukacji, a tym samym pomijania ogólnego dobra wychowanka ${ }^{6}$.

W okresie 1945-2016 poszczególne reformy szkolne powodowały zmiany w zakresie przedmiotowych programów kształcenia, co było jedną z przyczyn rozwoju badań metodycznych i dydaktycznych.

\section{Problematyka umiejscowienia dydaktyk przedmiotowych w systemie nauki}

W okresie powojennym ze względu na odmienne rozumienie celów i zadań dydaktyk przedmiotowych jako autonomicznych dyscyplin naukowych dostrzega się zróżnicowanie usytuowania tych dydaktyk w systemie nauki. Różnorodne rozumienie celów i zadań dydaktyk przedmiotowych zależało od poglądów zarówno dydaktyków ogólnych, jak i dydaktyków poszczególnych przedmiotów ogólnego kształcenia. Z przyjmowanego założenia, iż dydaktyki przedmiotowe są „uszczegółowioną dydaktyką ogólną”, wynikała ich podrzędność względem dydaktyk ogólnych ${ }^{7}$. Uzasadnione wydawało się wyprowadzenie celów i zadań dydaktyk przedmiotowych z określonych celów i zadań dydaktyk ogólnych. Różnice między dydaktykami przedmiotowymi natomiast uwarunkowane były ich odmiennymi treściami kształcenia. Usamodzielnianie się poszczególnych dydaktyk przedmiotowych wsparte uzyskiwanymi przez nie wynikami badań teoretycznych i empirycznych prowadziło z kolei do przekonania o niewłaściwym ich traktowaniu przez dydaktyków ogólnych. Sytuacja ta spowodowała zmianę poglądów dotyczących relacji dydaktyki ogólnej do dydaktyk przedmiotowych. Postulowano potrzebę wzajemnej współpracy obu rodzajów dydaktyk w weryfikowaniu i falsyfikowaniu przyjmowanych przez nie twierdzeń współzależnych ${ }^{8}$. Inne stanowiska określające miejsce dydaktyk przedmiotowych w systemie nauki wypływały z ich usytuowania między szczegółowymi dyscyplinami naukowymi a naukami pedagogicznymi. Jedni wskazywali bliższe ich powiązanie z podstawowymi dla nich naukami szczegółowymi - dla nich dydaktyki szczegółowe

${ }^{6}$ Eugenia Potulicka, Joanna Rutkowiak, Neoliberalne uwikłania edukacji (Kraków: Oficyna Wydawnicza „Impuls” 2010), 8-10.

${ }^{7}$ Jan Kulpa, „Dydaktyka ogólna i dydaktyki szczegółowe”. Prace z Dydaktyki Szkoły Wyższej 8 (1973): 13-28.

${ }^{8}$ Bolesław Niemierko, „Unowocześnienie procesu kształcenia - model dydaktyk szczegółowych", w: Resortowy Program Badań Podstawowych RP III-30. Materiały i opracowania $z$ roku 1986, t. 1 (Bydgoszcz: WSP 1987); Wincenty Okoń, Wprowadzenie do dydaktyki ogólnej (Warszawa: PWN 1987). 
stawały się jedynie dziedzinami stosowania rezultatów danych dziedzin naukowych, a drudzy, akcentując silniej kształcące i wychowawcze zadania dydaktyk przedmiotowych, traktowali je jako samodzielne dyscypliny naukowe?

Początkowo, w okresie powojennym dydaktycy ogólni przypisywali dydaktykom danych przedmiotów kształcenia ogólnego termin „dydaktyki szczegółowe”. Stało się tak na skutek odgórnie przyjętego podobieństwa dydaktyk przedmiotowych do dydaktyk ogólnych. Wskazywano na podobieństwa strukturalne, przyjmowane cele, zadania, metody i założenia metodologiczne, a nawet na analogiczne etapy rozwoju w dydaktykach nazywanych szczegółowymi. Sądzono, że dzięki dobremu poznaniu owych etapów rozwoju dydaktyk przedmiotowych można będzie opracować dla nich ogólny model stwarzający możliwość sterowania ich dalszym rozwojem ${ }^{10}$. Jak się okazało, dążenia do ujednolicenia dydaktyk szczegółowych z dydaktykami ogólnymi były charakterystyczne dla krajów socjalistycznych i prowadziły do zacierania różnicy między tymi dydaktykami.

W tym samym czasie odmienną tendencję zauważamy w rozwoju dydaktyk przedmiotowych w krajach zachodnioeuropejskich i amerykańskich, gdzie słabiej eksponowano powiązanie tych dydaktyk $\mathrm{z}$ dydaktyką ogólną ${ }^{11}$. Z biegiem czasu także na gruncie rodzimym dostrzec można stopniowe usamodzielnianie się dydaktyk przedmiotowych. Zjawiskiem normalnym stało się konkurowanie ze sobą kilku teorii i modeli dydaktyk przedmiotowych wynikających z odmiennego ujmowania przedmiotów i zjawisk poznawanych przez poszczególne dyscypliny naukowe, a także zróżnicowanego modelowania procesu dydaktycznego dostosowanego do potrzeb danego kształcenia przedmiotowego. Nie jest więc możliwe sformułowanie jednej, ogólnej teorii opisującej i wyjaśniającej problematyki wszystkich dydaktyk przedmiotowych. Pięcioletnie badania (1986-1990) rozwoju poszczególnych dydaktyk przedmiotowych wskazują na znaczne zróżnicowanie między takimi grupami dydaktyk przedmiotów, jak: zawodowe, humanistyczne czy matematyczno-przyrodnicze ${ }^{12}$. Tę ostatnią grupę dydaktyk omówimy bardziej dogłębnie.

${ }^{9}$ Danuta Cichy, „Stan dydaktyki biologii w Polsce”, Biologia w Szkole 5 (1987): 271-178; Wiesław Stawiński, „Kształcenie umiejętności i rozwijanie zainteresowań biologicznych”, Biologia $w$ Szkole 2 (1983).

${ }^{10}$ Niemierko, „Unowocześnienie procesu kształcenia”.

${ }^{11}$ Stawiński, Główne nurty rozwoju, 79-80; J. Šula, „Dydaktyka biologii jako nauka”, w: Prace z dydaktyki szkoły wyższej 8 (1973).

${ }_{12}$ Ryszard Janiuk, Synteza badań grup tematycznych przedmiotów matematyczno-przyrodniczych wykonywanych w ramach RP III-30 w latach 1986-1990 (Bydgoszcz: WSP 1990); Bolesław Niemierko, Synteza dorobku Resortowego Programu Badań Podstawowych III-30. Unowocześnianie procesu dydaktycznego - model dydaktyk szczegółowych 1986-1990 (Bydgoszcz: WSP 1990); Wiesław Stawiński, „Udział przyrodniczych czasopism dydaktycznych w rozwoju dydaktyki biologii”, w: Unowocześnianie procesu dydaktycznego - model dydaktyk szczegółowych, t. 4, red. Bolesław Niemierko (Bydgoszcz: WSP 1990). 
Na naszym rodzimym gruncie przez przedmiot badań dydaktyki ogólnej rozumiano wszelką działalność społeczną, obejmującą wszystkie szczeble pracy szkolnej oraz proces nauczania i uczenia się przy jednoczesnym ścisłym powiązaniu ze wszystkimi metodykami nauczania ${ }^{13}$. Dydaktycy polscy byli świadomi potrzeby dobrego rozpoznania relacji zachodzących między dydaktyką ogólną a przedmiotową. W przeciwnym razie błędne rozpoznanie tej relacji mogłoby być jednym z powodów izolacji dydaktyki ogólnej i jej oderwania się od przedmiotowych podstaw.

Rozwijające się dydaktyki przedmiotowe korzystają z naukowego dorobku dydaktyki ogólnej. Posługując się terminami i pojęciami ogólnodydaktycznymi, odpowiednio je konkretyzują i modyfikują. Krytycznie uwzględniają teoretyczne założenia dydaktyki ogólnej oraz charakterystyczne dla badań dydaktycznych metody. Zdarza się, że wyniki badań prowadzonych przez dydaktyków przedmiotowych prowadzą niekiedy do rewizji poglądów ogólnodydaktycznych, przyczyniając się do rozwoju dydaktyki ogólnej. Z biegiem czasu poszczególne dydaktyki przedmiotowe jako samodzielne dyscypliny naukowe dążą do kształtowania własnych teoretycznych postaw, własnej terminologii, założeń metodologii i metodyki podejmowanych działań organizujących pracę nauczyciela i ucznia z uwzględnieniem postulatów ergonomii (przystosowania warunków materialnych do efektywnego kształcenia) oraz prakseologii (podejmowania efektywnych działań).

Obserwując rozwój dydaktyk przedmiotowych, można postawić pytanie: czy dydaktyka ogólna może odgrywać ważną rolę w integrowaniu wielu nurtów badawczych dydaktyk przedmiotowych? Metametodologiczne analizy teoretycznych założeń i wyników badań dydaktyk przedmiotowych powinny się przyczyniać nie tylko do rewizji założeń ogólnodydaktycznych, ale przede wszystkim powinny odkrywać prawidłowości zachodzące w procesach nauczania, uczenia się i wychowania. W tym zakresie dydaktyka ogólna ze względu na swą funkcję koordynującą byłaby pomocna w zapobieganiu nadmiernej izolacji podejmowanych działań kształcenia i wychowania w zakresie dydaktyk przedmiotowych. Ponadto mając ponadprzedmiotowy charakter, byłaby uprawniona do inicjowania i koordynowania interdyscyplinarnych badań przy zachowaniu pełnej autonomii ich uczestników. Rozpoznanie tego typu relacji między dydaktyką ogólną a dydaktykami przedmiotowymi może wskazywać na taki rozwój dydaktyki ogólnej, który umożliwia badanie zagadnień charakterystycznych dla poszczególnych grup przedmiotowych. Obopólne korzyści płynące z tak rozumianej współpracy są na tyle ważne, że przemawiają za koniecznością pogłębiania badań wzajemnych ich relacji.

${ }^{13}$ Czesław Kupisiewicz, Podstawy dydaktyki ogólnej (Warszawa: PWN 1980), 12. 


\section{Usamodzielnienie się dydaktyk grupy przedmiotów przyrodniczych}

W niniejszym opracowaniu grupę przedmiotów przyrodniczych ograniczymy do fizyki, chemii oraz biologii i wybiórczo wskażemy na zagadnienia dydaktyczne $\mathrm{w}$ zakresie wymienionych przedmiotów oraz instytucjonalizację dydaktyki $\mathrm{w}$ środowisku akademickim.

Na początku XIX wieku na Wydziale Filozoficznym Uniwersytetu Warszawskiego dydaktyka, jako przedmiot studiów, odgrywała ważną rolę w przygotowywaniu nauczycieli przedmiotów przyrodniczo-matematycznych. Podobna sytuacja występowała w latach 20. tego wieku w Uniwersytecie Jagiellońskim. Należy też zauważyć, że w okresie międzywojennym pojawiają się pierwsze podręczniki z dydaktyki i metodyki nauczania poszczególnych przedmiotów przyrodniczych, przykładowo Zarys metodyki elementarnej kursu historii naturalnej Bronisława Dyakowskiego z 1923 roku czy wydana w 1932 roku przez Jana Harabaszewskiego Metodyka chemii, a w 1936 roku Dydaktyka chemii oraz publikacje z 1934 roku: Ludwika Jaxa-Bykowskiego Dydaktyka nauk biologicznych i Marii Polaczkówny - Dydaktyka geografii.

W latach 40. i 50. do szkół wyższych wprowadzono zajęcia z metodyk (metodyka biologii, metodyka chemii) i dopiero od lat 60. przywraca się nazwę przedmiotu „dydaktyka biologii”"14, a od lat 70. - „dydaktyka chemii”15. Pojęcie dydaktyki fizyki pojawiło się po raz pierwszy w 1967 roku w Zarządzeniu Ministra Oświaty i Szkolnictwa Wyższego, a pierwsze definicyjne określenie dydaktyki fizyki podał Władysław Wcisło, dla którego dydaktyka fizyki zajmuje się celami, treściami, procesem, metodami, środkami i procesem kształcenia przez nauczanie i uczenie się fizyki ${ }^{16}$.

W zakresie kształcenia przedmiotowego bardzo wyraźnie rozróżnia się metodykę nauczania danego przedmiotu od jego dydaktyki. Przez metodykę nauczania danego przedmiotu rozumie się najczęściej zbiór zasad oraz metod nauczania i uczenia się ${ }^{17}$ lub traktuje się ją jako dział dydaktyki przedmiotowej, który zajmuje się metodami nauczania ${ }^{18}$, a przed dydaktyką danego przedmiotu stawia się zadanie opracowania metodami naukowymi celów, treści

${ }^{14}$ Stawiński, Główne nurty rozwoju, 73.

${ }_{15}$ Dzieje dydaktyk przedmiotowych $w$ 65-letniej tradycji Uniwersytetu Pedagogicznego w Krakowie, red. Jan Rajmund Paśko, Katarzyna Potyrała, Jolanta Zielińska (Kraków: Wydawnictwo Naukowe UP 2011), 35-38.

${ }^{16}$ Marian Głowacki, Dydaktyka fizyki. Zagadnienia ogólne (Częstochowa: Wydawnictwo WSP 1994), 5.

${ }^{17}$ Tamże, 6 .

18 Šula, „Dydaktyka biologii”, 33. 
i procesu kształcenia oraz środków niezbędnych w nauczaniu danego przedmiotu $^{19}$. Przedmiot i zadania metodyki nauczania biologii zwięźle zostały ujęte przez Halinę Jaczewską, dla której

nauki zajmujące się teorią nauczania określonych, wyodrębnionych tematycznie przedmiotów noszą nazwę metodyk nauczania. Zakres ich zainteresowań pokrywa się z zagadnieniami dydaktyki ogólnej, ale w odniesieniu do danego przedmiotu nauczania. Każda metodyka przedmiotu nauczania [...] jest ściśle związana z dydaktyką ogólną, dostarcza jej konkretnych materiałów do uogólnień ${ }^{20}$.

Takie definicyjne podporządkowanie metodyki przedmiotu nauczania dydaktyce ogólnej jest odgórnie przyjętym ograniczeniem zadań danej metodyki do praktycznego stosowania zaleceń ogólnodydaktycznych.

Dyskusje dotyczące dookreślenia metodyki i dydaktyki przedmiotowej, podjęte w latach 60. i 70. ubiegłego wieku, rozpoczęły tak zwany okres syntezy, który zakończył się opracowaniem nowoczesnych podręczników dydaktyk przedmiotowych. Rezultatem tych badań są między innymi: Dydaktyka fizyki Mariana Głowackiego (1994), Dydaktyka chemii pod redakcją Andrzeja Burewicza i Hanny Gulińskiej (1993) czy Zarys dydaktyki biologii (1980) oraz Dydaktyka biologii $i$ ochrony środowiska (2000), obie prace pod redakcją Wiesława Stawińskiego ${ }^{21}$. $\mathrm{W}$ tak zwanym okresie syntezy badaniom naukowym poddano wiele zagadnień dydaktyk przedmiotowych, jednocześnie rozpoczęto odchodzenie od określania tych dydaktyk „dydaktykami szczegółowymi”, z racji tego, że rozpoznano wiele typowych zagadnień dydaktycznych mieszczących się w autonomicznym obszarze badań naukowych. Na podstawie wyników badań procesu nauczania poszczególnych przedmiotów ogólnokształcących tworzono teoretyczne uogólnienia, które zaowocowały daleko idącą specjalizacją w badaniach charakterystycznych dla danych przedmiotów kształcenia problematyką dydaktyczną ${ }^{22}$.

Śledząc rozwój dydaktyk przedmiotowych, można stwierdzić, iż są one dyscyplinami naukowymi, badającymi zaplanowaną działalność poznawczą procesu nauczania i uczenia się danego przedmiotu i podejmującymi racjonalną nad tym procesem refleksję metadydaktyczną dotyczącą przyjmowanych założeń, zadań, zasad i celów kształcenia. Przed dydaktykami przedmiotowymi są stawiane problemy teoretyczne i praktyczne. Teoretyczne problemy rozwiązuje się przez pojęciowe wyjaśnianie określonych zjawisk, a praktyczne przez wskazanie

${ }_{19}$ Grzegorz Białkowski, „Przedmiot, zadania i potrzeby dydaktyki fizyki”, Postępy Fizyki 30 (1979): 268.

${ }^{20}$ Cyt. za: Stawiński, Główne nurty rozwoju, 73.

${ }^{21}$ Andrzej Burewicz, Hanna Gulińska, Dydaktyka chemii (Poznań: Wydawnictwo Naukowe UAM 1993); Zarys dydaktyki biologii, red. Wiesław Stawiński (Warszawa: PWN 1980); Dydaktyka biologii i ochrony środowiska, red. Wiesław Stawiński (Warszawa-Poznań: Wydawnictwo Naukowe 2000).

${ }^{22}$ Dydaktyka biologii, 22. 
skutecznego działania w danym zakresie. Dydaktyki przedmiotowe zmierzają do coraz pełniejszego i głębszego poznania z jednej strony danych treści kształcenia, a $z$ drugiej - roli ucznia i nauczyciela w procesie nauczania i uczenia się danego przedmiotu. Dydaktyki przedmiotowe można traktować jako nauki otwarte, ponieważ dotyczą one wypracowywania teoretycznych modeli ciągle poznawanego, złożonego i zróżnicowanego procesu kształcenia. Dodatkowo uwzględniają one dorobek pokrewnych im dyscyplin naukowych: pedagogiki, psychologii, socjologii, neurologii, filozofii, teorii poznania i innych. Ze względu na interdyscyplinarny ich charakter są one autonomicznymi dziedzinami nauki, niesprowadzalnymi i nieredukowalnymi do żadnej innej dziedziny wiedzy naukowej ${ }^{23}$. Jednocześnie autonomiczność dydaktyk przedmiotowych nie powinna odizolowywać ich od metapedagogicznych i metadydaktycznych dyskusji dotyczących paradygmatyczności dydaktyk ogólnych. Z toczących się dyskusji można wyprowadzić wniosek, iż najlepszym rozwiązaniem dla rozwoju dydaktyk przedmiotowych jest ich otwieranie się na wiele paradygmatycznych propozycji i wybieranie z nich tych treści, które najpełniej dookreślają drogi prowadzące do samodzielności uczenia się i samowychowania ${ }^{24}$.

Wraz z usamodzielnianiem się dydaktyk przedmiotowych postępowała instytucjonalizacja dydaktyki w środowisku akademickim. W zakresie nauk przyrodniczych, zanim zaczęły być organizowane zakłady metodyki lub dydaktyki, do kształcenia akademickiego wprowadzano najpierw odpowiednie przedmioty metodyczne.

Ważnym wydarzeniem $\mathrm{w}$ historii rozwoju dydaktyk przedmiotowych w Polsce było zorganizowanie przez Zakład Dydaktyki Biologii WSP w Krakowie w 1970 roku I Ogólnopolskiego Seminarium Dydaktyki Biologii, na którym podjęto dyskusje o miejscu dydaktyki biologii pośród nauk biologicznych i dydaktyki ogólnej. W kolejnych latach zorganizowanie sekcji Dydaktyki Biologii przy Zarządzie Głównym Polskiego Towarzystwa im. Mikołaja Kopernika doprowadziło do przekształcenia się tradycyjnej metodyki nauczania biologii $\mathrm{w}$ dydaktykę biologii, dając tym samym początek dalszemu jej rozwojowi ${ }^{25}$. Warto też zauważyć, iż w 1957 roku na WSP w Krakowie powołano Zakład Metodyki Nauczania Biologii, który w 1961 roku został przekształcony w Zakład Dydaktyki Biologii kierowany przez Wiesława Stawińskiego. Na tej samej uczelni utworzona w 2003 roku Pracownia Dydaktyki Chemii została przekształcona w 2006 roku

${ }^{23}$ Krzysztof Śleziński, Zarys dydaktyki filozofii (Kraków: Oficyna Wydawnicza „Impuls” 2000), $15-16$.

${ }^{24}$ Dorota Klus-Stańska, Polska rzeczywistość dydaktyczna - paradygmatyczny taniec św. Wita, w: Paradygmaty współczesnej dydaktyki, red. Lucyna Hurło, Dorota Klus-Stańska, Majka Łojko (Kraków: Oficyna Wydawnicza „Impuls” 2009), 62-73; Agnieszka Nowak-Łojewska, Uwagi o edukacji w perspektywie obiektywizmu, konstruktywizmu i rekonstrukcjonizmu, w: Paradygmaty wspótczesnej dydaktyki, 148-161.

${ }_{25}$ Stawiński, Główne nurty rozwoju, 74. 
w Zakład Dydaktyki Chemii kierowany przez Jana Rajmunda Paśko. Z kolei Zakład Dydaktyki Fizyki utworzony został w 1977 roku i od połowy lat 80., przez blisko trzydzieści lat, kierował nim Wiesław Błasiak ${ }^{26}$.

W latach 1945-2016 w zakresie rozwoju dydaktyk przedmiotowych można zauważyć:

1. toczącą się dyskusję nad miejscem dydaktyk przedmiotowych w systemie nauki, ich relacji do dydaktyki ogólnej oraz do właściwych im dyscyplin naukowych;

2. usamodzielnianie się dydaktyk przedmiotowych i odchodzenie od określania ich „dydaktykami szczegółowymi”;

3. tworzenie $\mathrm{w}$ środowisku akademickim zakładów dydaktyk przedmiotowych;

4. opracowanie nowoczesnych podręczników dydaktyk przedmiotowych i programów kształcenia na wszystkich poziomach i etapach edukacyjnych;

5. rozwijanie dydaktyki ogólnej, dzięki empirycznym badaniom dydaktyk szczegółowych.

Streszczenie: W artykule przybliża się drogę dążenia dydaktyk szczegółowych, nazywanych także przedmiotowymi, do zdobycia samodzielności naukowej. Zwraca się także uwagę na ścisłą zależność dydaktyk przedmiotowych od dydaktyk ogólnych oraz specyfiki ich przedmiotów nauczania. Podkreśla się znaczenie rozwoju dydaktyk przedmiotowych w tworzeniu odpowiednich struktur środowiska akademickiego.

Słowa kluczowe: dydaktyka ogólna, dydaktyki przedmiotowe, metodyka, reforma edukacji, program kształcenia

\section{Bibliografia}

Białkowski, Grzegorz. „Przedmiot, zadania i potrzeby dydaktyki fizyki”. Postępy Fizyki 30 (1979): 268. Błasiak, Władysław. „Dzieje dydaktyki fizyki”. W: Dzieje dydaktyk przedmiotowych w 65-letniej tradycji Uniwersytetu Pedagogicznego w Krakowie, red. Jan Rajmund Paśko, Katarzyna Potyrała, Jolanta Zielińska, 53-59. Kraków: Wydawnictwo Naukowe UP, 2011.

Burewicz, Andrzej, Hanna Gulińska. Dydaktyka chemii. Poznań: Wydawnictwo Naukowe UAM, 1993.

Cichy, Danuta. „Stan dydaktyki biologii w Polsce”. Biologia w Szkole 5 (1987).

${ }^{26}$ Władysław Błasiak, Dzieje dydaktyki fizyki, w: Dzieje dydaktyk przedmiotowych w 65-letniej tradycji Uniwersytetu Pedagogicznego w Krakowie, red. Jan Rajmund Paśko, Katarzyna Potyrała, Jolanta Zielińska (Kraków: Wydawnictwo Naukowe UP 2011), 53-59. 
Dydaktyka biologii i ochrony środowiska, red. Wiesław Stawiński. Warszawa-Poznań: Wydawnictwo Naukowe, 2000.

Dzieje dydaktyk przedmiotowych w 65-letniej tradycji Uniwersytetu Pedagogicznego w Krakowie, red. Jan Rajmund Paśko, Katarzyna Potyrała, Jolanta Zielińska. Kraków: Wydawnictwo Naukowe UP, 2011.

Głowacki, Marian. Dydaktyka fizyki. Zagadnienia ogólne. Częstochowa: Wydawnictwo WSP, 1994.

Janiuk, Ryszard. Synteza badań grup tematycznych przedmiotów matematyczno-przyrodniczych wykonywanych w ramach RP III-30 w latach 1986-1990. Bydgoszcz: WSP, 1991.

Klus-Stańska, Dorota. „Polska rzeczywistość dydaktyczna - paradygmatyczny taniec św. Wita”. W: Paradygmaty współczesnej dydaktyki, red. Lucyna Hurło, Dorota Klus-Stańska, Majka Łojko. Kraków: Oficyna Wydawnicza „Impuls”, 2009.

Konieczna, Magdalena. Zasady dydaktyczne w kształceniu chemicznym. Warszawa: WSiP, 1991.

Kulpa, Jan. „Dydaktyka ogólna i dydaktyki szczegółowe”. Prace z Dydaktyki Szkoły Wyższej 8 (1973): 13-18.

Kupisiewicz, Czesław. Podstawy dydaktyki ogólnej. Warszawa: PWN, 1980.

Niemierko, Bolesław. Synteza dorobku Resortowego Programu Badań Podstawowych III-30. Unowocześnianie procesu dydaktycznego - model dydaktyk szczegółowych 1986-1990. Bydgoszcz: WSP, 1990.

Niemierko, Bolesław. „Unowocześnienie procesu kształcenia - model dydaktyk szczegółowych”. W: Resortowy Program Badań Podstawowych RP III-30. Materialy i opracowania $z$ roku 1986, t. 1. Bydgoszcz: WSP, 1987.

Nowak-Łojewska, Agnieszka. „Uwagi o edukacji w perspektywie obiektywizmu, konstruktywizmu i rekonstrukcjonizmu”. W: Paradygmaty współczesnej dydaktyki, red. Lucyna Hurło, Dorota Klus-Stańska, Majka Łojko. Kraków: Oficyna Wydawnicza „Impuls”, 2009.

O nauczaniu geografii, red. Benoit Brouillette, tłum. Józef Garbag. Warszawa: PZWS, 1970.

Okoń, Wincenty. Wprowadzenie do dydaktyki ogólnej. Warszawa: PWN, 1987.

Palka, Stanisław. „Zróżnicowanie teoretycznej wiedzy pedagogicznej a praktyka pedagogiczna”. W: Możliwości rozwijania i wykorzystywania teoretycznej wiedzy pedagogicznej, red. Stanisław Palka. Zeszyty Naukowe Uniwersytetu Jagiellońskiego MCLXI, Prace Pedagogiczne 22 (1995): 173-176.

Potulicka, Eugenia, Joanna Rutkowiak. Neoliberalne uwikłania edukacji. Kraków: Oficyna Wydawnicza „Impuls”, 2010.

Stawiński, Wiesław. Główne nurty rozwoju dydaktyki biologii. Warszawa: WSiP, 1992.

Stawiński, Wiesław. „Kształcenie umiejętności i rozwijanie zainteresowań biologicznych”. Biologia $w$ Szkole 2 (1983).

Stawiński, Wiesław. „Udział przyrodniczych czasopism dydaktycznych w rozwoju dydaktyki biologii”. W: Unowocześnianie procesu dydaktycznego - model dydaktyk szczegółowych, red. Bolesław Niemierko, t. 4. Bydgoszcz: WSP, 1990.

Šula J. „Dydaktyka biologii jako nauka”. Prace z Dydaktyki Szkoły Wyższej 8 (1973).

Szymański, Mirosław. „Podstawy teoretyczne reform szkolnych”. W: Możliwości rozwijania i wykorzystywania teoretycznej wiedzy pedagogicznej, red. Stanisław Palka. Zeszyty Naukowe Uniwersytetu Jagiellońskiego MCLXI, Prace Pedagogiczne 22 (1995): 57-64.

Śleziński, Krzysztof. Zarys dydaktyki filozofii. Kraków: Oficyna Wydawnicza „Impuls”, 2000.

Wybrane zagadnienia $z$ dydaktyki ogólnej, red. Anna Łukaszewska, Stanisław Palka. Kraków: Wyd. Uniwersytetu Jagiellońskiego, 1988.

Zarys dydaktyki biologii, red. Wiesław Stawiński. Warszawa: PWN, 1980. 
